\title{
Milk somatic cell count and its relationship with milk yield and quality traits in Italian water buffaloes
}

\author{
A. Costa, ${ }^{1} \odot$ G. Neglia, ${ }^{2 *} \odot$ G. Campanile, ${ }^{2}$ and M. De Marchi ${ }^{1} \odot$ \\ ${ }^{1}$ Department of Agronomy, Food, Natural resources, Animals and Environment, University of Padova, 35020 Legnaro (PD), Italy \\ ${ }^{2}$ Department of Veterinary Medicine and Animal Production, Federico II University of Naples, 80137 Napoli (NA), Italy
}

\begin{abstract}
In Southern Italy, buffalo (Bubalus bubalis) milk is mostly intended for the manufacture of Mozzarella di Bufala Campana Protected Denomination of Origin (PDO) cheese. Despite the economic boost of the last 2 decades, the buffalo farming system should be improved to maximize the efficiency of the dairy industry, improve yield and quality of milk and cheese, and work toward better animal welfare. Milk somatic cell count (SCC) is used worldwide as an indicator of udder health in individual milk and is useful for monitoring farm hygiene in bulk milk. Mastitis data are currently not available on a large scale in Italy; thus, SCC is essential for identifying animals with suspected udder infection and inflammation. Moreover, high milk SCC is associated with altered composition and acidity, and poor technological properties of milk. However, payment systems of the PDO area are based simply on the delivered volume of milk rather than on quality characteristics. Hence, currently there are no penalties for elevated SCC in bulk milk in the Italian buffalo dairy industry. In addition, SCC for buffalo milk is not mentioned by either the European Community regulations or the PDO protocol, evidencing a lack of rules for the maximum SCC limit. To provide a phenotypic characterization of SCC at the population level and to improve knowledge on buffalo milk quality, 876,299 test-day records of 70,156 buffaloes reared in the PDO area were analyzed. Data revealed that around 11\% of herd-test-dates ( $\geq 5$ animals sampled each) showed average milk SCC $\geq 400,000$ cells $/ \mathrm{mL}$ (i.e., above the threshold fixed by the European Community for bovine milk). This suggests that there is room to improve SCC at both the farm and individual level. Within first parity, more than 28 and $15 \%$ of lactations had average SCC $\geq 200,000$ and $\geq 300,000$ cells/mL, respectively. Both percentages increased with parity and were 39 and
\end{abstract}

Received December 4, 2019.

Accepted January 28, 2020.

*Corresponding author: neglia@unina.it
$25 \%$ in sixth parity, respectively. Supporting this, the proportion of lactations with average SCC $\geq 500,000$ cells $/ \mathrm{mL}$ increased from $6 \%$ in first parity to $12 \%$ in sixth parity. Milk yield and SCC were negatively correlated with each other, especially when SCC level was high. An ANOVA was carried out on test-day record milk yield and composition traits, with fixed effects of parity, lactation stage, class of somatic cell score $(\mathrm{n}=$ 6 ), month of calving, and their interactions; buffalo, herd-test-date, and residual were considered random effects. Significantly lower milk yield and lactose percentage were estimated in progressively higher classes of somatic cell score, whereas no significant differences were observed for fat and protein percentages. This is the first attempt to investigate milk SCC in a large data set of Italian dairy buffaloes. These findings may be helpful for defining reliable and effective SCC thresholds to be adopted whenever specific penalties for high SCC are included in milk payment systems. Finally, these results could be used in mastitis monitoring plans aiming to reduce SCC and udder issues at both the individual and farm levels in the Italian buffalo population.

Key words: buffalo milk, somatic cell count, milk yield, milk quality

\section{INTRODUCTION}

Buffalo milk quality is a hot topic for the Italian dairy industry because it directly affects technological characteristics of milk (Manuelian et al., 2017). In Southern Italy, buffalo milk is mostly intended for the manufacture of Mozzarella di Bufala Campana (MBC), a Protected Denomination of Origin (PDO) cheese (EU Regulation no. 1107/1996 of 12 June 1996; EU, 1996) appreciated all over the world for its organoleptic and nutritional quality, with demand and export growing year by year (CLAL, 2018). The number of buffaloes (Bubalus bubalis) farmed in the designated PDO area has increased in the last $20 \mathrm{yr}$, driven by favorable market perspectives (Consorzio Tutela Mozzarella di Bufala Campana, 2017). In fact, the number of heads registered in the official recording system increased 
from 18,950 in 2006 to 34,655 in 2018 in the Campania region, which currently hosts more than $80 \%$ of the buffaloes of the PDO area (Italian Breeders Association, AIA, 2019a). However, in the same region, the number of farms did not show the same trend and only slightly increased from 105 (2006) to 121 (2018; AIA, 2019a).

In 2018, the national average milk production at 270 DIM reached $2,357 \mathrm{~kg}$, with a mean fat percentage $(\mathbf{F P})$ of $8.03 \pm 0.99 \%$ and a mean protein percentage $(\mathbf{P P})$ of $4.63 \pm 0.32 \%$ (AIA, 2019a). Nevertheless, the sustainable improvement of animal performance, herd management practices, and milk quality still represents a crucial challenge for the Italian dairy buffalo sector. In fact, the progressive intensification of the system (i.e., increased herd size, greater individual milk productivity, and the application of intensive or semi-intensive breeding techniques mostly designed for bovines) has led to managerial issues and to consumer sensitivity regarding animal welfare and food safety (De Rosa et al., 2005). Moreover, in the era of antibiotic microbial resistance and animal welfare, improving health and limiting antibiotic use in buffaloes is strongly recommended.

Mastitis is a disease with great impact in terms of costs in dairy species, including buffaloes. Economic losses generally refer to reduced milk yield (MY) and impaired quality, veterinary treatments, culling, and cost of replacement. In Italian buffaloes, prevalence and incidence of mastitis tend to be quite high, indicating poor hygiene and insufficient management care (Fagiolo and Lai, 2007). In addition, it is difficult to estimate the incidence of mastitis at the present time due to scarce communication among stakeholders and to suboptimal data management. The SCC represents the milk concentration of somatic cells, mostly leukocytes, and is the most adopted indicator of udder health in livestock worldwide. A strong positive relationship exists between SCC and mastitis in buffalo (Moroni et al., 2006; Bansal et al., 2007; Tripaldi et al., 2010). In addition, whereas mastitis diagnosis by veterinarians is binary (i.e., presence or absence), test-day (TD) SCC data are quantitative, longitudinally recorded, noninvasive, easy to measure, and more objective.

According to EU Regulation no. 853/2004 of 29 April 2004 (EU, 2004), an SCC limit exists only for bovine bulk tank milk and there is no limit for SCC in the MBC PDO protocol, evidencing a lack of maximum threshold permitted in buffaloes. According to PDO protocol, milk for MBC manufacture must simply contain FP $\geq 7.20 \%$ and $\mathrm{PP} \geq 4.20 \%$. As a consequence, chronic cases with high milk SCC often are not registered and not culled in buffalo farms. Finally, the scarce interest in SCC in the Italian dairy buffalo sector has an economic element. Currently, no penalties are present for bulk milk with elevated SCC in payment systems because most systems are only based on the delivered volume of milk $(\mathrm{kg})$ and rarely reward FP or PP. These factors, together with scarce communication within the chain, certainly contribute to suboptimal bulk MY, milk quality, and herd health.

Overall, very few studies have evaluated the influence of SCC on milk features in buffaloes, especially in large data sets. For instance, Tripaldi et al. (2003) investigated the effect of SCC on MY, composition traits, and coagulation properties in 1,859 Italian buffalo milk samples. In Europe, the effect of high SCC on MY and milk quality traits has been investigated only in few experimental studies under controlled conditions with relatively small data sets (Bansal et al., 2007; Sharif et al., 2007; Osman et al., 2009). Therefore, this study aimed to improve the knowledge on these aspects in the current population of Italian buffaloes by providing an overview of SCC at both the animal and farm levels on a large scale and by estimating the effect of different levels of SCC on MY and traditional composition traits.

\section{MATERIALS AND METHODS}

\section{Data}

A total of $1,414,449$ milk TD samples collected between January 2013 and December 2017 from 106,388 buffaloes were available from the official database of the Italian Breeders Association (AIA; Rome, Italy). Information on birth date, daily MY, parity, and DIM for each observation was also provided. The daily MY (at $24 \mathrm{~h}$ ) in animals milked once a day was calculated by AIA through specific coefficients from the single MY available (AIA, 2019b).

Milk FP, PP, and lactose percentage (LP) were predicted using infrared spectroscopy at the milk laboratory of the Breeders Association of Campania region (Benevento, Italy) with a MilkoScan FT6000 (Foss Electric A/S, Hillerød, Denmark), and SCC was assessed using a Fossomatic FC (Foss Electric A/S). For each TD, the fat-to-protein ratio (FPR), an indicator of negative energy balance, was calculated as FPR = $\mathrm{FP} / \mathrm{PP}$.

The editing criteria included restrictions on DIM (5 to 400), parity (first to sixth), and age at calving within parity (mean $\pm 1 \mathrm{SD}$ ). Considering MY, FP, PP, FPR, and LP, values were retained only if within the range of mean $\pm 3 \mathrm{SD}$, whereas for SCC the minimum and maximum were fixed at 1,000 and 10,000,000 cells/ $\mathrm{mL}$, respectively. For statistical purposes, SCC was transformed into SCS through the conventional formula 
proposed by Ali and Shook (1980) to achieve a normal distribution. Within each lactation of a buffalo, at least 5 TD were needed for inclusion in statistical analysis. Finally, contemporary groups (herd-test-date; HTD) with fewer than 5 buffaloes sampled were removed, ending up with 70,156 animals in 336 herds with 876,299 TD in 125,703 lactations. For SCS, MY, and composition traits, Pearson correlations were estimated in SAS (version 9.4; SAS Institute Inc., Cary, NC).

\section{Analysis of Variance}

To estimate the effect of different levels of SCS on MY and composition, 6 classes of SCS were designed from its overall mean $(\mu ; 2.93$ units) and SD $(\sigma ; 1.75$ units) so that the frequency of records could follow a normal distribution. In particular, criteria were as follows:

- Class 1 (42,258 TD): SCS $\leq(\mu-1.5 \times \sigma)$

- Class $2(81,005$ TD): $(\mu-1.5 \times \sigma)<\mathrm{SCS} \leq$ $(\mu-1 \times \sigma)$

- Class 3 (346,674 TD): $(\mu-1 \times \sigma)<\operatorname{SCS} \leq \mu$

- Class $4(267,393$ TD): $\mu<\operatorname{SCS} \leq(\mu+1 \times \sigma)$

- Class 5 (70,155 TD): $(\mu+1 \times \sigma)<\mathrm{SCS} \leq(\mu+$ $1.5 \times \sigma)$

- Class 6 (68,814 TD): SCS $>(\mu+1.5 \times \sigma)$

For a better modeling of lactation stage effect, 11 blocks of 30 DIM each were created, except for the first (5-30 DIM), the second to last (270-310 DIM), and the last (310-400 DIM) blocks. The ANOVA was carried out in ASREML 4.1 (Gilmour et al., 2015) with the following model:

$$
\begin{gathered}
\mathrm{y}_{\mathrm{ijklmn}}=\mu+\text { Par }_{\mathrm{i}}+\text { Lact }_{\mathrm{j}}+\text { Month }_{\mathrm{k}}+\mathrm{SCS}_{1} \\
+\left(\text { Par } \times \text { Lact }_{\mathrm{ij}}+(\text { Par } \times \text { Month })_{\mathrm{ik}}+(\text { Par } \times \text { SCS })_{\mathrm{il}}\right. \\
+(\text { Lact } \times \text { Month })_{\mathrm{ik}}+(\text { Lact } \times \text { SCS })_{\mathrm{jl}} \\
+(\text { Month } \times \text { SCS })_{\mathrm{kl}}+\mathrm{ID}_{\mathrm{m}}+\mathrm{HTD}_{\mathrm{n}}+\mathrm{e}_{\mathrm{ijklmn}},
\end{gathered}
$$

where $\mathrm{y}$ is the dependent variable (MY, FP, PP, FPR, and LP); Par is the fixed effect of the ith class of parity; Lact is the fixed effect of the jth stage of lactation; Month is the fixed effect of the kth month of calving; SCS is the fixed effect of the lth class of SCS; (Par $x$ Lact) is the fixed effect of interaction between parity and lactation stage; (Par $\times$ Month) is the fixed effect of interaction between parity and month of calving; (Par $\times$ SCS) is the fixed effect of interaction between parity and class of SCS; (Lact $\times$ Month) is the fixed effect of interaction between stage of lactation and month of calving; (Lact $\times$ SCS) is the fixed effect of interaction between lactation stage and class of SCS; (Month $\times$ SCS) is the fixed effect of interaction between month of calving and class of SCS; and ID $(\mathrm{n}=70,156)$, HTD $(\mathrm{n}=11,303)$, and e are the random effects of the mth female buffalo, the nth contemporary group, and the residual, respectively. The Bonferroni $t$-test was used for testing differences among least squares means $(P$ $<0.05)$.

\section{RESULTS AND DISCUSSION}

\section{Data Overview}

In the present study, MY, FP, PP, FPR, LP, and SCS averaged $9.01 \mathrm{~kg} / \mathrm{d}, 8.12 \%, 4.71 \%, 1.73,4.77 \%$, and 2.93 units, respectively. The coefficient of variation ranged from 6.71 (LP) to $59.73 \%$ (SCS). Overall, milk composition mirrored that of all national buffaloes subscribed to official recording (Associazione Nazionale Allevatori Specie Bufalina; ANASB, 2017) and was comparable with the results of Manuelian et al. (2017). However, MY was slightly above the average value $(8.60 \mathrm{~kg} / \mathrm{d})$ reported by AIA (2019a) for the year 2018, calculated for standard lactations (270 DIM) of buffaloes between first and third parity farmed in the Campania region.

Table 1 shows the number and percentage of lactations characterized by at least 1 TD SCC above a certain threshold, hereby referred to as a peak. As expected, the proportion of lactations with at least 1 peak increased with parity order. Within all parities, more than $65 \%$ of buffaloes presented at least 1 peak of SCC $\geq 200,000$ cells $/ \mathrm{mL}$ (Table 1 ). Furthermore, within first parity, more than 52 and $42 \%$ of animals had at least 1 peak of SCC $\geq 300,000$ and $\geq 400,000$ cells/mL, respectively; greater percentages were found in subsequent parities (Table 1).

In first parity, $28.36 \%$ of lactations had average SCC (based on at least 5 TD) $\geq 200,000$ cells $/ \mathrm{mL}$; this percentage was $39.05 \%$ in sixth parity (Table 1 ). Overall, the number of lactations with average SCC above a certain threshold increased with parity; for example, $6.35 \%$ of lactations had average SCC $\geq 500,000$ cells/ $\mathrm{mL}$ in first parity, and this percentage doubled (12.31\%) in sixth parity (Table 1).

Finally, 37.37, 20.06, 11.35, and $6.62 \%$ of HTD showed average SCC (based on at least 5 animals sampled) $\geq 200,000, \geq 300,000, \geq 400,000$, and $\geq 500,000$ cells/ $\mathrm{mL}$, respectively. In this case, if bovine raw milk legislation would be applied (EU Regulation no. 853/2004 of 29 April 2004; EU, 2004), bulk milk of 1,283 HTD (11.35\% of total HTD) would be dismissed, exceeding the limit of 400,000 cells/mL. 


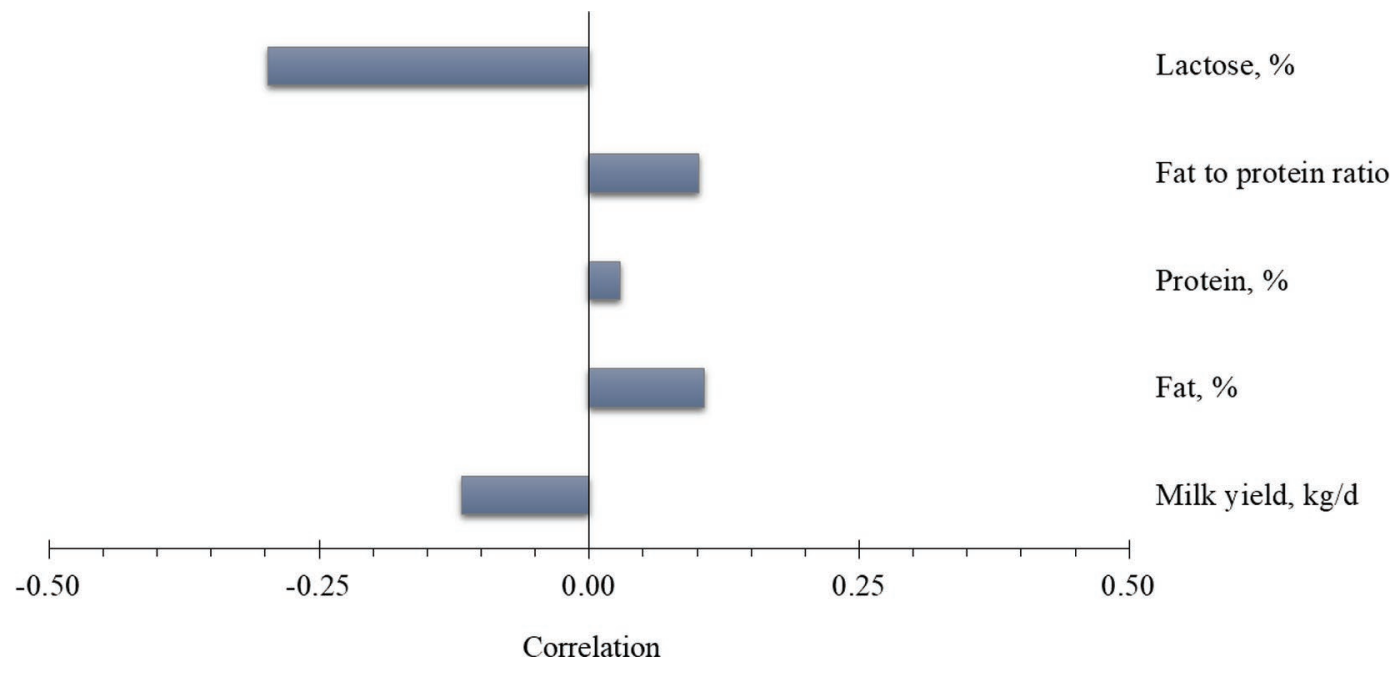

Figure 1. Direction and magnitude of Pearson correlations of buffalo milk SCS with milk yield, composition traits, and fat-to-protein ratio $(P<0.001)$ in the whole data set $(876,299$ test-day records $)$.

\section{Correlations}

Phenotypic correlations of SCS with all traits $(P<$ $0.001)$ for the entire data set are graphically presented in Figure 1. Negative correlations were obtained between SCS and both MY and LP, whereas positive correlations were obtained between SCS and each of FP, PP, and FPR. In terms of magnitude, the strongest and the weakest correlations of SCS were those with LP (-0.30) and PP (0.03), respectively.

In dairy cattle, several studies focused on the negative relationship between LP and SCC and recognized LP as a potential indicator of mastitis and udder health (Pyörälä, 2003; Ebrahimie et al., 2018; Costa et al., 2019b). The correlation between SCS and LP exists at both the phenotypic and genetic levels in dairy cattle (Haile Mariam and Pryce, 2017; Costa et al., 2019a,b) and has also been observed in buffalo species in some phenotypic studies (Cerón-Muñoz et al., 2002; Tripaldi et al., 2010; Pasquini et al., 2018). In fact, the decrease in LP in animals with udder inflammation seems to be related to an impaired epithelial integrity of mammary gland alveoli (Costa et al., 2019b). In particular, when mastitis occurs, the permeability of alveolar epithelium increases, leading to a lactose loss in the bloodstream and urine and thus to an alteration of milk-blood osmotic equilibrium (Fox et al., 2015; Costa et al., 2019b). Extra ions (e.g., $\mathrm{Na}^{+}$) migrate from blood to re-establish the equilibrium; this explains why mastitic milk is characterized by altered taste, coagulation characteristics, and acidity (Fox et al., 2015). In fact, high values of SCC are known to be associated with impaired milk coagulation properties (De Marchi et al., 2013; Visentin et al., 2015; Franzoi et al., 2020), protein composition (Mc Dermott et al., 2016), and mineral content (Visentin et al., 2016).

Given the damage of mammary tissue by inflammation factors and pathogens, a negative correlation between SCS and MY was expected and confirmed the effect of udder health issues on individual productivity

Table 1. Total number of lactations in each parity and number (n) and proportion (\%) of lactations with at least 1 test-day (TD) SCC $\geq 200,000$ cells/mL (peak A), at least 1 TD SCC $\geq 300,000$ cells $/ \mathrm{mL}$ (peak B), and at least 1 TD SCC $\geq 400,000$ cells $/ \mathrm{mL}$ (peak C) as well as with different levels of average SCC (cells/mL)

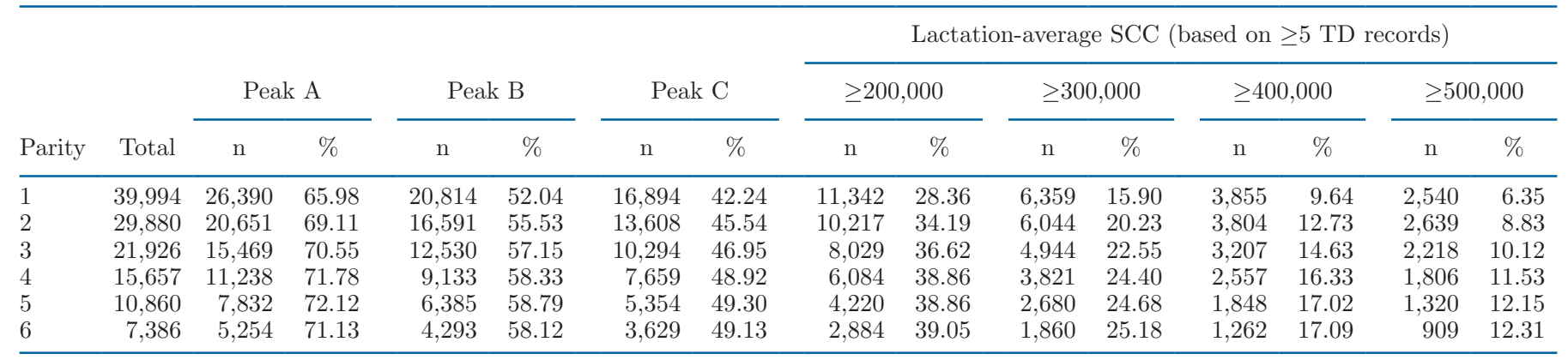


Table 2. Pearson correlations among SCS, milk yield $(\mathrm{kg} / \mathrm{d})$, composition traits $(\%)$, and fat-to-protein ratio in lactations presenting different levels of average SCC (based on $\geq 5$ test-day records)

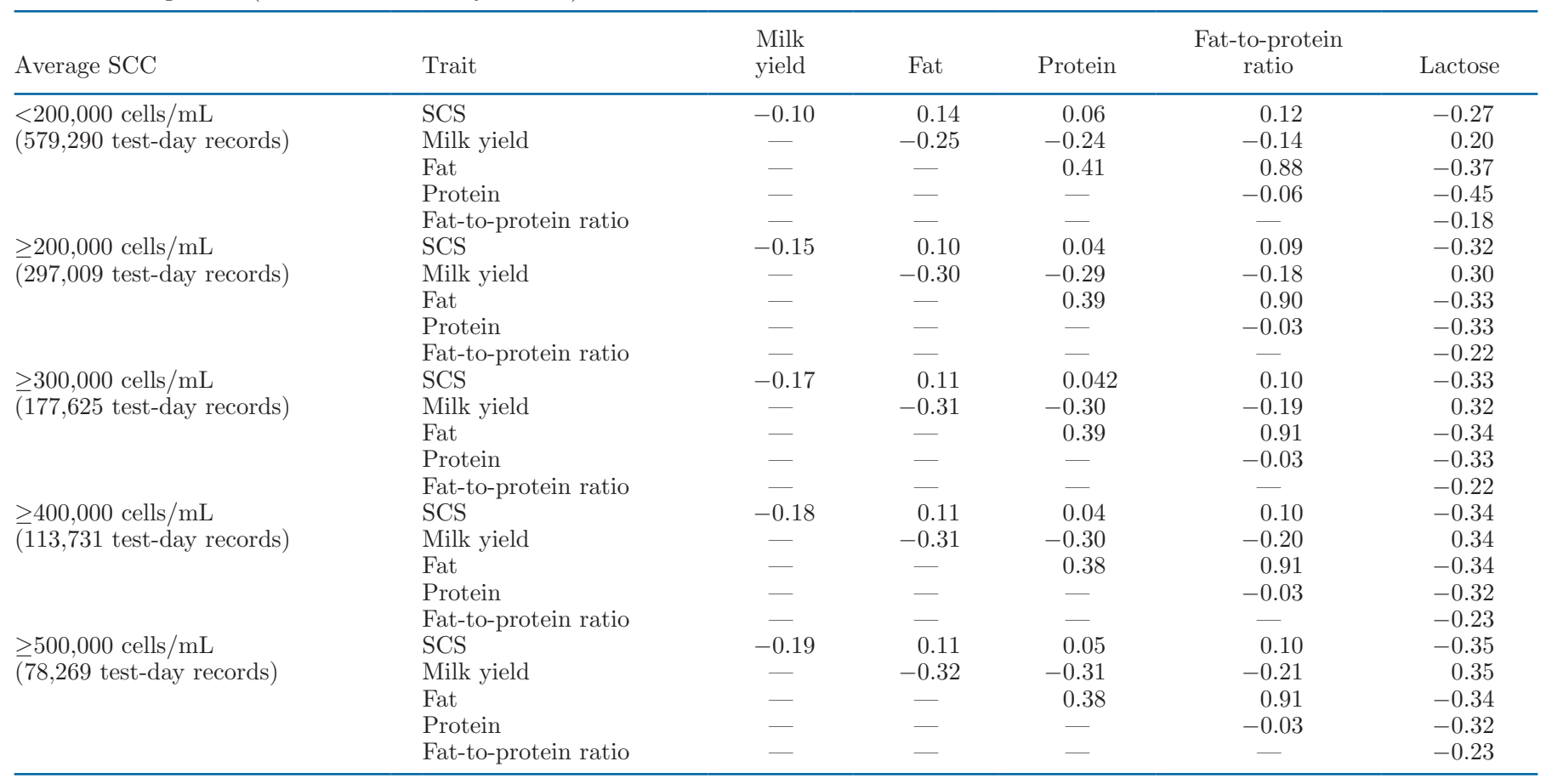

(Gonçalves et al., 2018; Hadrich et al., 2018). Positive but weak associations were found between SCS and both FP and PP, supporting findings of AspilcuetaBorquis et al. (2010) in 4,907 Brazilian buffaloes. According to Forsbäck et al. (2010) and Malek dos Reis et al. (2013), total PP tends to increase during mastitis in cattle, likely due to a greater permeability of alveolar epithelium that allows transition of serum proteins and enzymes from blood (Forsbäck et al., 2010). However, the same authors found that CN percentage was lower in cows with mastitis than in healthy cows. This may further explain why mastitis is known to be detrimental to buffalo cheese yield (Tripaldi et al., 2003, 2010). The dilution effect (MY reduction) may have contributed to the positive correlation between SCS and PP but also to the one between SCS and FP. In fact, the latter confirmed what has been reported in previous studies for both cattle and buffalo (Pyörälä, 2003; Bansal et al., 2005; Tripaldi et al., 2010).

Considering that FPR is widely used as an indicator of energy balance and hyperketonemia in buffaloes, the positive correlation (0.10) with SCS indicated that animals at greater risk of negative energy balance may be more susceptible to udder issues and vice versa. Indeed, a positive correlation between mastitis and ketosis has been estimated in dairy animals (Jamrozik and Schaeffer, 2012; Hossein-Zadeh, 2016; Jamrozik et al., 2016; Costa et al., 2019a).
To evaluate the behavior of relationships at different levels of SCC, all correlations were separately estimated in 5 subsets of lactations with average SCC $<200,000$, $\geq 200,000, \geq 300,000, \geq 400,000$, and $\geq 500,000$ cells $/ \mathrm{mL}$ (Table 2). The correlation between SCS and MY was negative in the 5 subsets (Table 2), averaging -0.15 and peaking $(-0.19)$ in lactations with average SCC $\geq 500,000$ cells $/ \mathrm{mL}$. The correlations of SCS with FP, $\mathrm{PP}$, and FPR were positive and showed less variation across subsets compared with the correlation between SCS and MY (Table 2). As previously discussed, negative and moderate correlations between SCS and LP were expected (Table 2) and ranged from -0.27 (lactations with average $\mathrm{SCC}<200,000$ cells $/ \mathrm{mL}$ ) to -0.35 (lactations with average SCC $\geq 500,000$ cells $/ \mathrm{mL}$ ). This suggested a stronger dependency of SCS and LP in buffaloes with full-blown udder inflammation and supported the idea that LP, together with SCC, may be a useful indicator of udder health in this species.

\section{Fixed Effects}

The quota of variance explained by HTD ranged between $24.84 \%$ (LP) and $29.78 \%$ (FPR), overall suggesting a moderate dependency on temporary environmental effects. The fixed effect of class of SCS (Table 3) was significant for all traits at $P<0.001$. For both MY and LP, least squares means were statistically equal 
Table 3. Least squares means ${ }^{1}$ and proportion of variance explained by herd-test-date (HTD) of milk yield and quality traits for each class of SCS

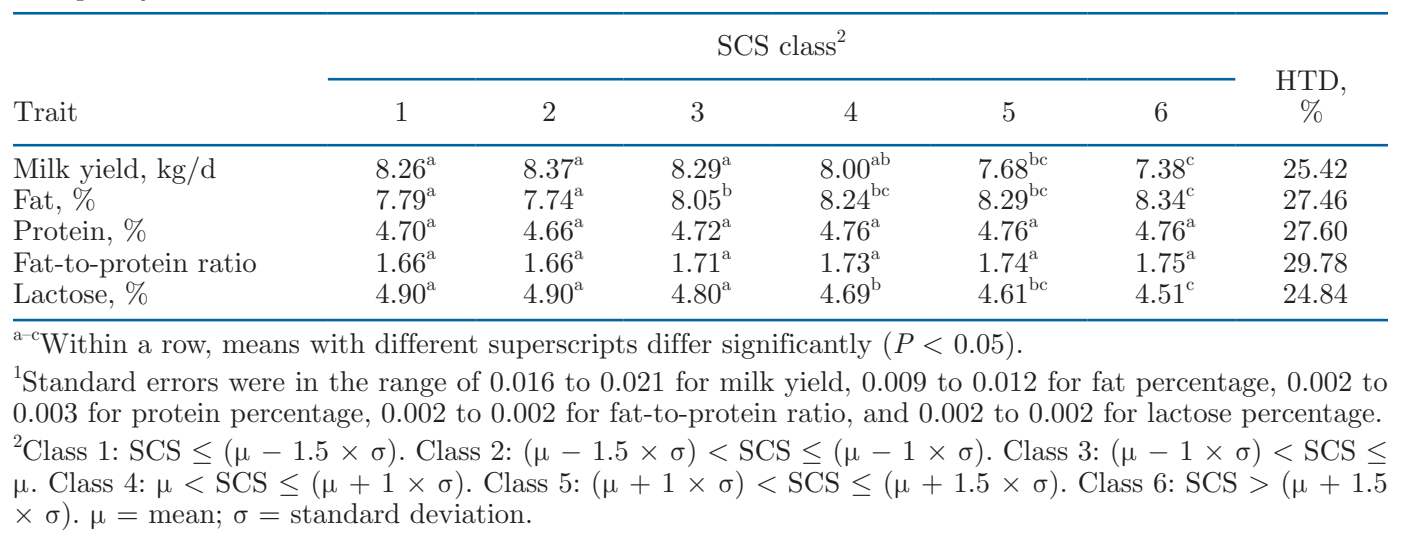

in the first 3 classes, whereas the FP of class 3 was different from the FP of classes 1 and 2 . On the other hand, least squares means of both PP and FPR were statistically equal across the 6 classes.

The effect of interaction between class of SCS and parity was significant $(P<0.05)$ for all traits (Table 4). Regarding MY, the maximum value was observed in third parity in all classes of SCS with a gradual decrease afterward. Both MY and LP increased from class 1 to class 2 , with progressive reduction until class 6 (Table 4) in all parities. On the contrary, FP and PP increased from class 2 to class 6 and FPR increased with class of SCS. In general, these findings suggested that TD of class 1 (very low SCS) were not charac-

Table 4. Least squares means (SE in parentheses) of buffalo milk yield, composition traits, and fat-to-protein ratio for the fixed effect of interaction between parity and SCS class

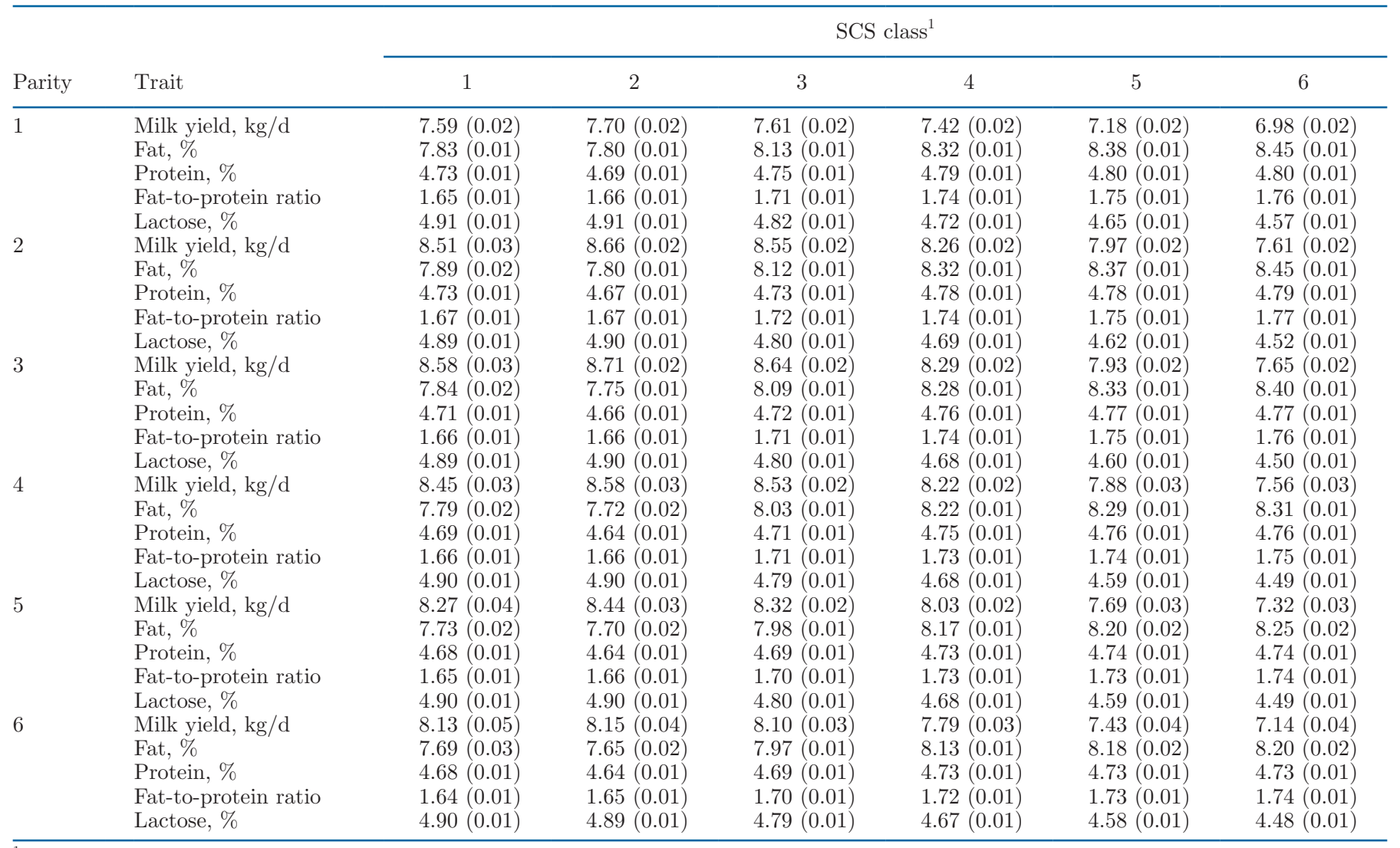

${ }^{1}$ Class 1: SCS $\leq(\mu-1.5 \times \sigma)$. Class 2: $(\mu-1.5 \times \sigma)<$ SCS $\leq(\mu-1 \times \sigma)$. Class $3:(\mu-1 \times \sigma)<$ SCS $\leq \mu$. Class $4: \mu<$ SCS $\leq(\mu+1 \times$ $\sigma)$. Class 5: $(\mu+1 \times \sigma)<\operatorname{SCS} \leq(\mu+1.5 \times \sigma)$. Class 6: $\operatorname{SCS}>(\mu+1.5 \times \sigma) \cdot \mu=$ mean; $\sigma=$ standard deviation. 

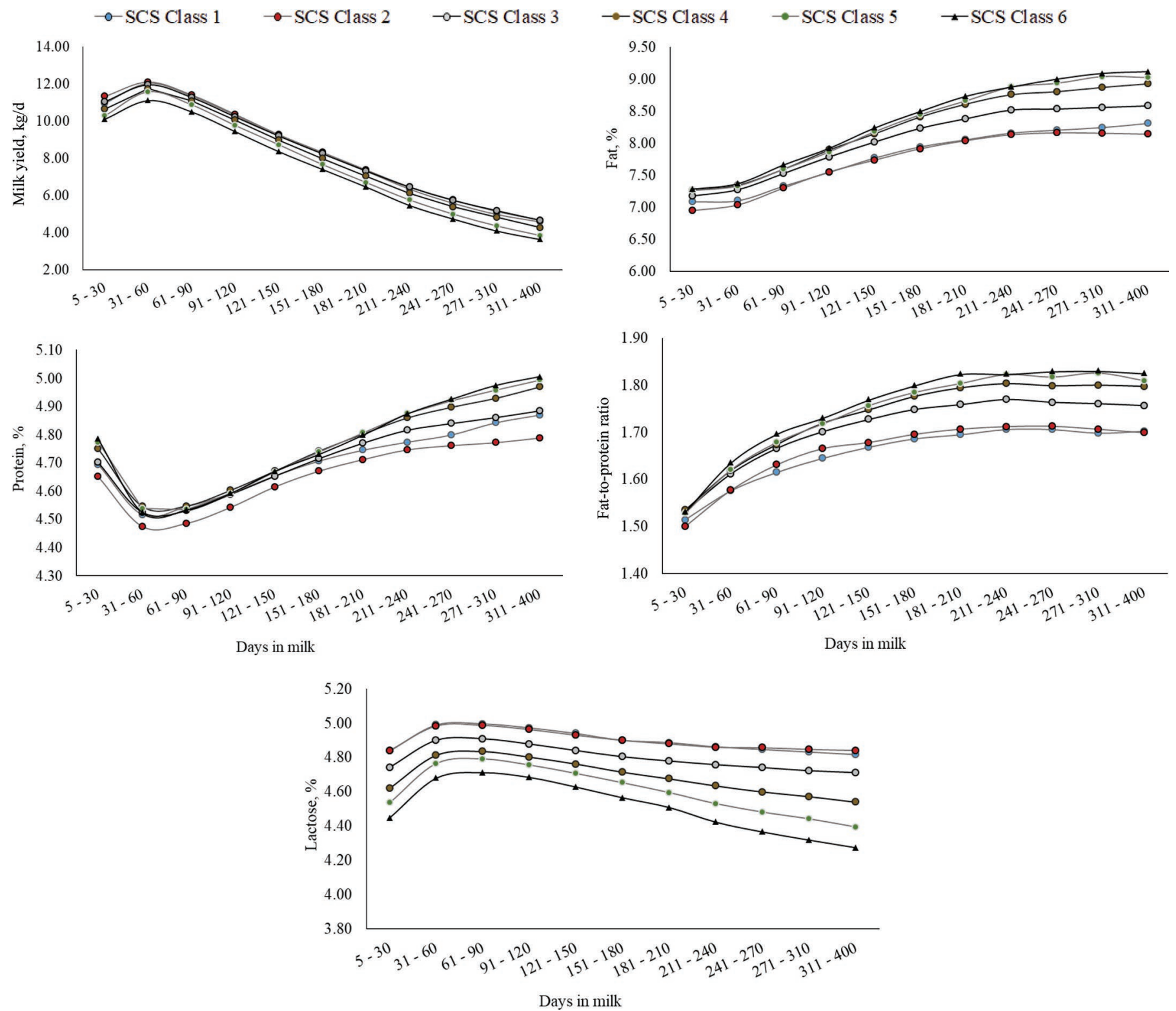

Figure 2. Parity-specific lactation curves (LSM) of buffalo milk yield, composition traits, and fat-to-protein ratio for the 6 classes of SCS. Class 1: SCS $\leq(\mu-1.5 \times \sigma)$. Class $2:(\mu-1.5 \times \sigma)<\mathrm{SCS} \leq(\mu-1 \times \sigma)$. Class $3:(\mu-1 \times \sigma)<\mathrm{SCS} \leq \mu$. Class $4: \mu<$ SCS $\leq(\mu+1 \times$ $\sigma)$. Class 5: $(\mu+1 \times \sigma)<\operatorname{SCS} \leq(\mu+1.5 \times \sigma)$. Class 6: SCS $>(\mu+1.5 \times \sigma) \cdot \mu=$ mean; $\sigma=$ standard deviation.

terized by the greatest MY. In fact, as reported for bovines (Franzoi et al., 2020), extremely low values of SCC may not reflect the real physiological status and could be potential alerts for udder issues.

The effect of the interaction between class of SCS and stage of lactation was highly significant $(P<0.001)$ for all traits and is graphically depicted in Figure 2. Although the shapes of lactation curves in different classes of SCS were similar within trait, they presented different intercepts. In fact, in all classes of SCS, lactation curves of LP and MY exhibited a peak in early lactation and a subsequent decrease. On the contrary, both FP and PP were at maximum at the end of lactation, as effected by milk dilution. In all classes of SCS, FPR increased in early lactation and then stabilized around mid lactation. These outcomes suggested that the evolution of the traits (i.e., MY and composition traits) during the lactation was scarcely influenced by level of SCS per se.

The effect of interaction between class of SCS and month of calving (Figure 3) was significant for all traits at $P<0.001$. In buffalo, the month of calving is a 
relevant factor for both productive and reproductive performances; in fact, this species is considered a shortday breeder and is very sensitive to daily number of hours of light. Therefore, buffaloes increase reproductive activity when daylight hours decrease (Campanile et al., 2010). In temperate regions (above the equator), the natural reproductive season takes place in winter and early spring, with calvings concentrated in late summer and autumn. However, considering that the peak of the milk market requirement for $\mathrm{MBC}$ cheese manufacture is in the spring and summer periods, out-
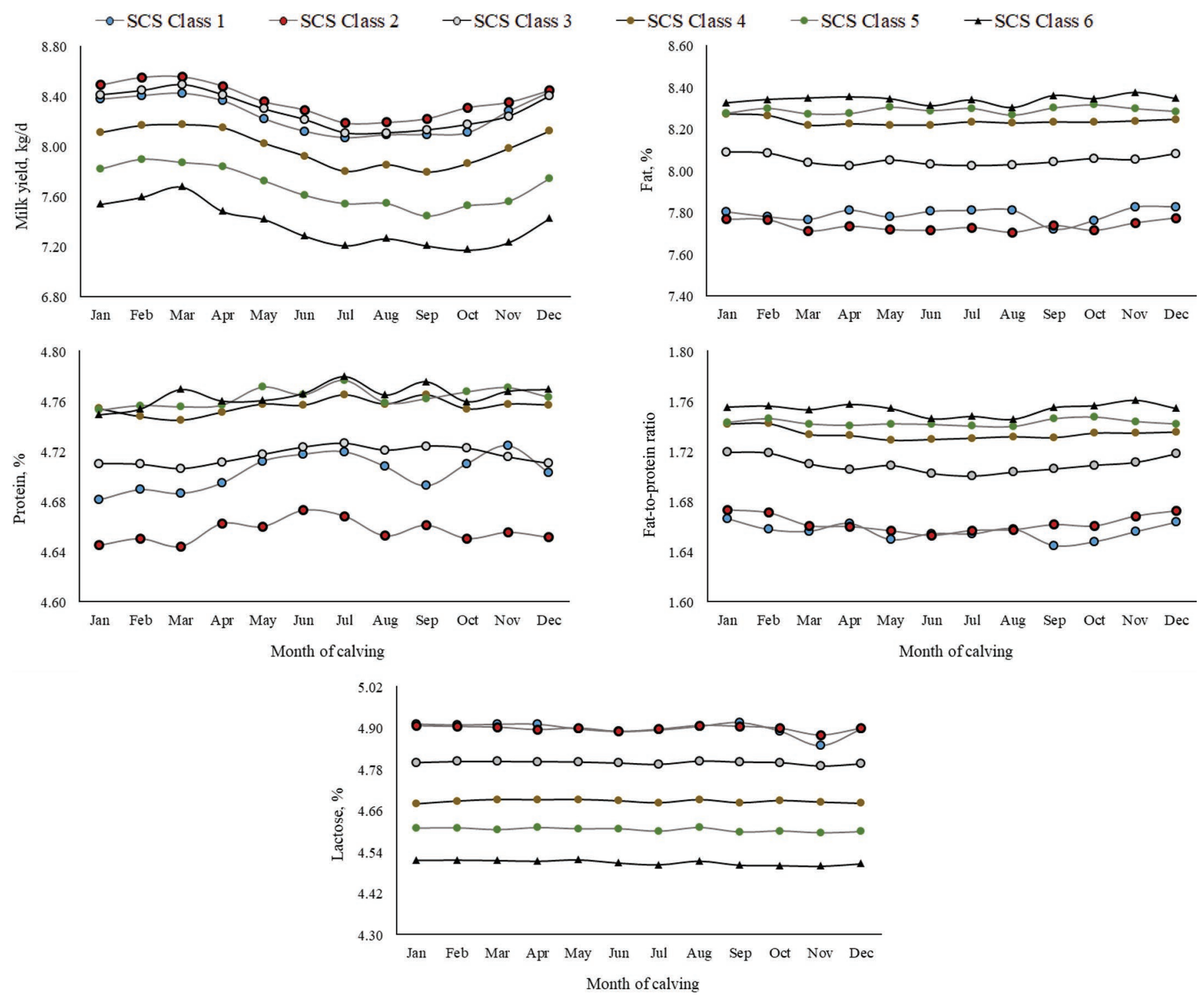

Figure 3. Least squares means of buffalo milk yield, composition traits, and fat-to-protein ratio for the interaction between fixed effects of class of SCS and month of calving. Class 1: SCS $\leq(\mu-1.5 \times \sigma)$. Class 2: $(\mu-1.5 \times \sigma)<$ SCS $\leq(\mu-1 \times \sigma)$. Class 3: $(\mu-1 \times \sigma)<$ SCS $\leq \mu$. Class 4: $\mu<\operatorname{SCS} \leq(\mu+1 \times \sigma)$. Class 5: $(\mu+1 \times \sigma)<\operatorname{SCS} \leq(\mu+1.5 \times \sigma)$. Class 6 : SCS $>(\mu+1.5 \times \sigma)$. $\mu=$ mean; $\sigma=$ standard deviation. 
the 6 classes of SCS across months of calving. On the other hand, PP was more variable, in particular in classes 1 and 2. Slightly greater PP were observed in buffaloes that calved in late spring and early summer compared with buffaloes that calved in the rest of the year (Figure 3).

\section{CONCLUSIONS}

Milk SCC can be used to monitor both farm hygiene and udder health in buffaloes. In the near future, Italian milk payment systems may be updated to include penalties for high SCC. To estimate the effect of different levels of SCS on MY and quality, 876,299 individual milk TD of buffaloes reared in the area of MBC PDO cheese were analyzed. Within first parity, more than 28 and $15 \%$ of lactations were characterized by average SCC $\geq 200,000$ and $\geq 300,000$ cells $/ \mathrm{mL}$, respectively. Furthermore, almost $10 \%$ of buffaloes in first parity had average SCC $\geq 400,000$ cells $/ \mathrm{mL}$. The proportion of lactations with average SCC $\geq 500,000$ cells $/ \mathrm{mL}$ doubled from first $(6 \%)$ to sixth parity $(12 \%)$. We demonstrated that SCS is negatively correlated with MY, particularly in animals with high SCS; that is, the correlation moved from -0.10 (buffaloes with lactation-average $\mathrm{SCC}<200,000$ cells $/ \mathrm{mL}$ ) to -0.19 (buffaloes with lactation-average SCC $\geq 500,000$ cells/ $\mathrm{mL}$ ). According to the ANOVA, lower MY and LP were estimated in progressively higher classes of SCS, whereas FP and PP were not unfavorably affected by SCS. Therefore, milk SCC may be monitored to reduce the prevalence of mastitis in Italian buffaloes, make appropriate managerial choices, and improve farm efficiency and profitability. In addition, this study should be useful to breeders' organizations when designing selection indices for mastitis resistance and udder health. From a practical point of view, these findings might be seen as a first step to stimulate future projects aimed at increasing buffalo farmers' sensitivity to SCC and understanding its effect on milk coagulation traits and cheese yield as well as on other novel milk traits.

\section{ACKNOWLEDGMENTS}

The authors acknowledge the Laboratory of the Breeders Association of Campania region (Benevento, Italy) for providing the data used in the present study. This research was funded by Campania region: PSR REGIONE CAMPANIA 2014-2020 - misura 16.1.2 (Project 'STRABUF' - Strategie per il miglioramento della redditività dell'allevamento bufalino. CUP: B68H19005200009). The authors have not stated any conflicts of interest.

\section{REFERENCES}

Ali, A. K. A., and G. E. Shook. 1980. An optimum transformation for somatic cell concentration in milk. J. Dairy Sci. 63:487-490. https: //doi.org/10.3168/jds.S0022-0302(80)82959-6.

Aspilcueta-Borquis, R. R., F. A. Araujo Neto, F. Baldi, A. B. Bignardi, L. G. D. Albuquerque, and H. Tonhati. 2010. Genetic parameters for buffalo milk yield and milk quality traits using Bayesian inference. J. Dairy Sci. 93:2195-2201. https://doi.org/10.3168/jds .2009-2621.

AIA (Associazione Italiana Allevatori). 2019a. Statistiche ufficiali. Accessed Sep. 25, 2019. http://bollettino.aia.it/Contenuti.aspx?CD _GruppoStampe=RS\&CD_Specie=C4.

AIA (Associazione Italiana Allevatori). 2019b. Ufficio centrale dei controlli sulla produttività animale. Accessed Oct. 15, 2019. http:/ /www.aia.it/aia-website/it/settori/area-tecnica/ufficio-sviluppo/ ufficio-centrale-dei-controlli-sulla-produttivita-animale.

ANASB (Associazione Nazionale Allevatori Specie Bufalina). 2017. Dati ANASB. Accessed Sep. 20, 2018. http://www.anasb.it/ statistiche/.

Bansal, B. K., J. Hamann, N. Grabowski, and K. B. Singh. 2005. Variation in the composition of selected milk fraction samples from healthy and mastitis quarters, and its significance for mastitis diagnosis. J. Dairy Res. 72:144-152. https://doi.org/10.1017/ S0022029905000798.

Bansal, B. K., J. Hamann, O. Lind, S. T. Singh, and P. S. Dhaliwal. 2007. Somatic cell count and biochemical components of milk related to udder health in buffaloes. Ital. J. Anim. Sci. 6(Suppl. 2):1035-1038. https://doi.org/10.4081/ijas.2007.s2.1035.

Campanile, G., P. S. Baruselli, G. Neglia, D. Vecchio, B. Gasparrini, L. U. Gimenes, L. Zicarelli, and M. J. D'Occhio. 2010. Ovarian function in the buffalo and implications for embryo development and assisted reproduction. Anim. Reprod. Sci. 121:1-11. https:// doi.org/10.1016/j.anireprosci.2010.03.012.

Campanile, G., G. Neglia, D. Vecchio, M. Russo, and L. Zicarelli. 2009. Pregnancy in buffalo cows. Pages 31-91 in Pregnancy Protein Research. M. O'Leary and J. Arnett, ed. Nova Science Publishers Inc., Haupauge, NY.

Cerón-Muñoz, M., H. Tonhati, J. Duarte, J. Oliveira, M. Muñoz-Berrocal, and H. Jurado-Gámez. 2002. Factors affecting somatic cell counts and their relations with milk and milk constituent yield in buffaloes. J. Dairy Sci. 85:2885-2889. https://doi.org/10.3168/jds S0022-0302(02)74376-2.

CLAL. 2018. Production of Mozzarella di Bufala Campana PDO, Italy. Accessed Sep. 15, 2019. https://www.clal.it/en/?section= mozzarella_bufala_campana.

Consorzio Tutela Mozzarella di Bufala Campana. 2017. Consorzio di Tutela della Mozzarella di Bufala Campana. Accessed Oct. 20, 2019. https://www.mozzarelladop.it/consorzio/i-numeri-della-dop.

Costa, A., C. Egger-Danner, G. Mészáros, C. Fuerst, M. Penasa, J. Sölkner, and B. Fuerst-Waltl. 2019a. Genetic associations of lactose and its ratios to other milk solids with health traits in Austrian Fleckvieh cows. J. Dairy Sci. 102:4238-4248. https://doi.org/ $10.3168 /$ jds.2018-15883.

Costa, A., N. Lopez-Villalobos, N. W. Sneddon, L. Shalloo, M. Franzoi, M. De Marchi, and M. Penasa. 2019b. Invited review: Milk lactose - Current status and future challenges in dairy cattle. J. Dairy Sci. 102:5883-5898. https://doi.org/10.3168/jds.2018-15955.

De Marchi, M., V. Toffanin, M. Cassandro, and M. Penasa. 2013. Prediction of coagulating and noncoagulating milk samples using mid-infrared spectroscopy. J. Dairy Sci. 96:4707-4715. https://doi .org/10.3168/jds.2012-6506.

De Rosa, G., F. Napolitano, F. Grasso, C. Pacelli, and A. Bordi. 2005. On the development of a monitoring scheme of buffalo welfare at farm level. Ital. J. Anim. Sci. 4:115-125. https://doi.org/10.4081/ ijas.2005.115.

Ebrahimie, E., F. Ebrahimi, M. Ebrahimi, S. Tomlinson, and K. R. Petrovski. 2018. A large-scale study of indicators of sub-clinical mastitis in dairy cattle by attribute weighting analysis of milk composition features: Highlighting the predictive power of lactose 
and electrical conductivity. J. Dairy Res. 85:193-200. https://doi org/10.1017/S0022029918000249.

EU. 1996. European Regulation no. 1107/1996 of 12 June 1996. Accessed Nov. 15, 2019. https://eur-lex.europa.eu/legal-content/EN/ $\mathrm{TXT} / \mathrm{PDF} /$ ?uri=CELEX:31996R1107\&from $=\mathrm{EN}$.

EU. 2004. European Regulation no. 853/2004 of 29 April 2004. Accessed Oct. 30, 2019. https://eur-lex.europa.eu/LexUriServ/ LexUriServ.do?uri=OJ:L:2004:139:0055:0205:EN:PDF

Fagiolo, A., and O. Lai. 2007. Mastitis in buffalo. Ital. J. Anim. Sci. 6(Suppl. 2):200-206. https://doi.org/10.4081/ijas.2007.s2.200.

Forsbäck, L., H. Lindmark-Månsson, A. Andrén, and K. SvennerstenSjaunja. 2010. Evaluation of quality changes in udder quarter milk from cows with low-to-moderate somatic cell count. Animal 4:617626. https://doi.org/10.1017/S1751731109991467.

Fox, P. F., T. Uniacke-Lowe, P. L. H. McSweeney, and J. A. O'Mahony. 2015. Dairy Chemistry and Biochemistry. Springer International, Basel, Switzerland.

Franzoi, M., C. L. Manuelian, M. Penasa, and M. De Marchi. 2020. Effects of somatic cell score on milk yield and mid-infrared predicted composition and technological traits of Brown Swiss, Holstein Friesian, and Simmental cattle breeds. J. Dairy Sci. 103:791-804. https://doi.org/10.3168/jds.2019-16916.

Gilmour, A. R., B. J. Gogel, B. R. Cullis, S. Welham, and R. Thompson. 2015. ASReml User Guide Release 4.1 Structural Specification. VSN International Ltd., Hemel Hempstead, UK.

Gonçalves, J. L., R. I. Cue, B. G. Botaro, J. A. Horst, A. A. Valloto, and M. V. Santos. 2018. Milk losses associated with somatic cell counts by parity and stage of lactation. J. Dairy Sci. 101:43574366. https://doi.org/10.3168/jds.2017-13286.

Hadrich, J. C., C. A. Wolf, J. Lombard, and T. M. Dolak. 2018. Estimating milk yield and value losses from increased somatic cell count on US dairy farms. J. Dairy Sci. 101:3588-3596. https://doi .org/10.3168/jds.2017-13840.

Haile-Mariam, M., and J. E. Pryce. 2017. Genetic parameters for lactose and its correlation with other milk production traits and fitness traits in pasture-based production systems. J. Dairy Sci. 100:3754-3766. https://doi.org/10.3168/jds.2016-11952.

Hossein-Zadeh, N. G. 2016. Modelling lactation curve for milk fat to protein ratio in Iranian buffaloes (Bubalus bubalis) using non-linear mixed models. J. Dairy Res. 83:334-340. https://doi.org/10.1017/ S0022029916000340.

Jamrozik, J., A. Koeck, G. J. Kistemaker, and F. Miglior. 2016. Multiple-trait estimates of genetic parameters for metabolic disease traits, fertility disorders, and their predictors in Canadian Holsteins. J. Dairy Sci. 99:1990-1998. https://doi.org/10.3168/jds .2015-10505.

Jamrozik, J., and L. R. Schaeffer. 2012. Test-day somatic cell score, fat-to-protein ratio and milk yield as indicator traits for sub-clinical mastitis in dairy cattle. J. Anim. Breed. Genet. 129:11-19. https://doi.org/10.1111/j.1439-0388.2011.00929.x.

Malek dos Reis, C. B., J. R. Barreiro, L. Mestieri, M. A. Porcionato, and M. V. dos Santos. 2013. Effect of somatic cell count and mastitis pathogens on milk composition in Gyr cows. BMC Vet. Res. 9:67. https://doi.org/10.1186/1746-6148-9-67.
Manuelian, C. L., G. Visentin, C. Boselli, G. Giangolini, M. Cassandro, and M. De Marchi. 2017. Prediction of milk coagulation and acidity traits in Mediterranean buffalo milk using Fourier-transform mid-infrared spectroscopy. J. Dairy Sci. 100:7083-7087. https:// doi.org/10.3168/jds.2017-12707.

McDermott, A., G. Visentin, M. De Marchi, D. P. Berry, M. A. Fenelon, P. M. O'Connor, O. A. Kenny, and S. McParland. 2016. Prediction of individual milk proteins including free amino acids in bovine milk using mid-infrared spectroscopy and their correlations with milk processing characteristics. J. Dairy Sci. 99:3171-3182. https://doi.org/10.3168/jds.2015-9747.

Moroni, P., C. Sgoifo Rossi, G. Pisoni, V. Bronzo, B. Castiglioni, and P. J. Boettcher. 2006. Relationships between somatic cell count and intramammary infection in buffaloes. J. Dairy Sci. 89:9981003. https://doi.org/10.3168/jds.S0022-0302(06)72165-8.

Osman, K. M., M. I. El-Enbaawy, N. A. Ezzeldeen, and H. M. G. Hussein. 2009. Mastitis in dairy buffalo and cattle in Egypt due to Clostridium perfringens: Prevalence, incidence, risk factors and costs. Rev. Sci. Tech. 28:975-986. https://doi.org/10.20506/rst.28 3.1936.

Pasquini, M., A. Osimani, S. Tavoletti, I. Moreno, F. Clementi, and M. F. Trombetta. 2018. Trends in the quality and hygiene parameters of bulk Italian Mediterranean buffalo (Bubalus bubalis) milk: A three year study. Anim. Sci. J. 89:176-185. https://doi.org/10 .1111/asj.12916.

Pyörälä, S. 2003. Indicators of inflammation in the diagnosis of mastitis. Vet. Res. 34:565-578. https://doi.org/10.1051/vetres:2003026.

Sharif, A., T. Ahmad, M. Q. Bilal, A. Yousaf, and G. Muhammad. 2007. Effect of severity of sub-clinical mastitis on somatic cell count and lactose contents of buffalo milk. Pak. Vet. J. 27:142-144.

Tripaldi, C., G. Palocci, M. Miarelli, M. Catta, S. Orlandini, S. Amatiste, R. Di Bernardini, and G. Catillo. 2010. Effects of mastitis on buffalo milk quality. Asian-Australas. J. Anim. Sci. 23:1319-1324.

Tripaldi, C., S. Terramoccia, S. Bartocci, M. Angelucci, and V. Danese. 2003. The effects of the somatic cell count on yield, composition and coagulating properties of Mediterranean buffalo milk. Asian-Australas. J. Anim. Sci. 16:738-742.

Visentin, G., A. McDermott, S. McParland, D. P. Berry, O. A. Kenny, A. Brodkorb, M. A. Fenelon, and M. De Marchi. 2015. Prediction of bovine milk technological traits from mid-infrared spectroscopy analysis in dairy cows. J. Dairy Sci. 98:6620-6629. https://doi.org/ 10.3168/jds.2015-9323.

Visentin, G., M. Penasa, P. Gottardo, M. Cassandro, and M. De Marchi. 2016. Predictive ability of mid-infrared spectroscopy for major mineral composition and coagulation traits of bovine milk by using the uninformative variable selection algorithm. J. Dairy Sci 99:8137-8145. https://doi.org/10.3168/jds.2016-11053.

\section{ORCIDS}

A. Costa @ https://orcid.org/0000-0001-5353-8988

G. Neglia (๑) https://orcid.org/0000-0002-0989-6072

M. De Marchi $\odot$ https://orcid.org/0000-0001-7814-2525 